\title{
ACRL Board actions, June 1994
}

\section{Highlights of the Annual Conference meetings of the ACRL Board of Directors}

$\mathbf{T}$ he Board of Directors of ACRL met twice in Miami Beach on June 25 and June 28, 1994. The Board's varied agenda ranged from the routine to the innovative and included approving several new standards and guidelines and developing a new process for managing ACRL planning. The following are the highlights of the actions agreed on during those meetings.

Approved five priorities for ACRL for 1994 95 (see sidebar for full text of the priorities).

Endorsed the Research and Statistics Policy Statement of the ALA Committee on Research and Statistics.

Established an MLA International Bibliography in American Libraries Discussion Group.
Approved the nominations of the following individuals to the International Federation of Library Associations' (IFLA) Standing Committees for the sections indicated: Mary Noel Gouke, Ohio State University-Section on Social Science Libraries; Marty Kesselman, Rutgers University-Section on Science and Technology; and Joseph Boissé, University of California, Santa Barbara-Section on University and General Libraries.

Approved a Business Plan for ACRL Publications.

\section{Approved the Rare Books and Manuscripts} Section's (RBMS) request to cosponsor a twoday symposium with the Antiquarian Booksellers' Association of America (ABAA) on bookseller-librarian relations in October 1995.

\section{Approved a resolution of appreciation to} Evan Ira Farber on the occasion of his retirement as college librarian at Earlham College. Farber was recognized for his many years of outstanding service to ACRL including his election to ACRL President (1978-79) and elec-

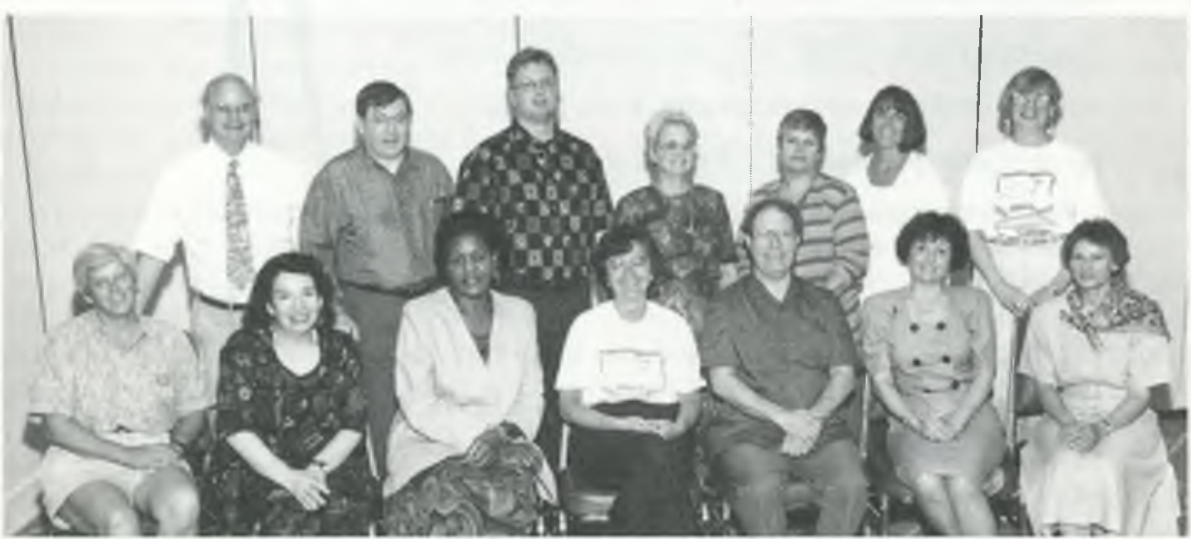

ACRL Board 1993 -94: Back row: Paul Dumont, Thomas Peischl, Ray E. Metz, Barbara Wittkopf, Sandra Ready, Frances Maloy, Karin Begg Borei; front row: Shelley Phipps, Rochelle Sager, Althea Jenkins, Susan Martin, Thomas Kirk, Jacquelyn McCoy, Linda Phillips. 


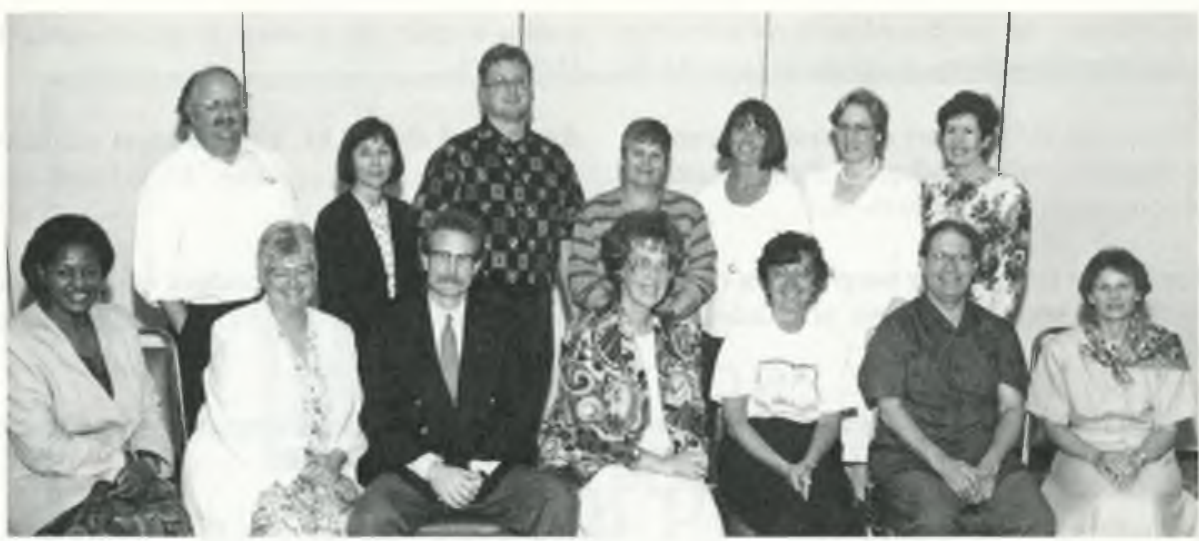

ACRL Board 1994-95: Back row: Bernard Fradkin, Victoria Montavon, Ray E. Metz, Sandra Ready, Frances Maloy, Helen Spalding, Jill Fatzer; front row: Althea Jenkins, Mary Reichel, Lee Hisle, Patricia Breivik, Susan Martin, Thomas Kirk, Linda Phillips.

tion to a second term on the ACRL Board of Directors (1989-93).

\section{Endorsed the criteria and procedures from} the ACRL Standards and Accreditation Committee for selecting, updating, and distributing a list of accreditation advisors.

Approved the following policies, guideline, standard, and rescission upon recommendation of the ACRL Standards and Accreditation Committee:

1) policy to permit units to request an expedited review of ACRL Standards and Guidelines in cases where it is clear that the document can be renewed with only minor changes;

2) policy to publish final versions of standards and guidelines in CERL News;

3) "Standards for Community, Junior, and Technical College Learning Resources programs";

4) "Guidelines regarding thefts in libraries";

5) continuation of the Standards for University Libraries in their present form until the next scheduled review in 1999-2000; and

6) rescission of the "Guidelines on Manuscripts and Archives."

\section{Endorsed resolution of thanks from RBMS}

to Nora Quinlan and William Brown for their outstanding performance in providing excellent local arrangements for the 35th RBMS Preconference.

Accepted the self-review report and recommended continuation of the following units:
Professional Liaison Committee, Education and Behavioral Sciences Section, and Science and Technology Section.

Endorsed a tribute to Patricia Sabosik, former editor of Choice, for her ten years of excellent service to Cboice and to ACRL.

\section{Established a task force to develop an RFP} (request for proposals) and budget, and to conduct a study on the view of regional accrediting agencies towards library standards. The task force will consist of two representatives each from the College Libraries, Community and Junior College Libraries, and University Libraries sections; one representative from the ACRL Standards and Accreditation Committee; and one liaison from the ALA Standards and Accreditation Committee.

\section{Endorsed resolutions on the Copyright} Reform Act and on LSCA Reauthorization.

Disbanded upon request the Performance/ Output Measures Discussion Group

Approved a process including the following steps to guide ACRL planning:

1) suspended use of the existing Strategic Plan;

2) directed use of the Annual Statement of Priorities (see sidebar) to guide the Board, Planning Committee, Budget and Finance Committee, staff, and other ACRL programmatic and operational decisions during the year;

3) established the Planning Committee as a 
subcommittee of the Board with membership from elected members of the Board and ACRL units; and

4) appointed an Interim Planning Committee charged with developing a new strategic plan and priorities for 1995-96.

Approved a temporary suspension of committee and section reviews scheduled after March 1, 1995.

Approved timelines and composition of the Search Committee for a new Choice editor. The goal is to offer the position to an individual by May 1995.

Approved the ACRL 1995 budget of: Revenues: $\$ 1,633,037$; expenses: $\$ 1,533,228$; fund balance: $\$ 762,535$.

And the Cboice 1995 budget of: Revenue: $\$ 1,591,500$; expenses: $\$ 1,545,228$; fund balance: $\$ 848,903$.

Rescinded special programming funding policy for chapters.

\section{ACRL priorities $1994-95$}

Provide leadership for the higher education community on library and information issues. ACRL realizes the need for visibility within the higher education community and the valuable role that library and information professionals play. Accordingly, ACRL maintains a presence with higher education and other information related organizations. The association will expand its visibility by identifying existing programs that provide opportunities for mutual participation. New programs will be identified to foster cooperation. For example, ACRL will begin to hold an Issues Forum that will include librarians, faculty, academic administrators, and computing center professionals. In addition, the newly established Task Force on Certification for Librarians and Information Professionals will begin to examine the issues surrounding this topic.

Strengthen the association's commitment to diversity. ACRL understands the value of providing members the opportunity to experience, discuss, and explore diversity. An understanding of diversity will lead to improved services to library users. ACRL will iclentify program areas, develop plans, and initiate at least one program - such as a diversity mentorship-for academic librarians. A survey will be conducted that will identify job satisfaction issues among racial and ethnic groups.

Identify programs and delivery mechanisms that will enhance the ability of ac- ademic librarians serving the information needs of the higher education community. Educational programs that have a tradition with the membership (annual conferences, national conferences, preconferences) will continue to be available. ACRL will explore the viability and feasibility of providing continuing professional development opportunities using the Internet, teleconferences, videotapes, and regional institutes, and will make recommendations about the next steps to be taken

Use the information obtained from the membership survey and the Midwinter planning session to update the Strategic Plan. To move the association forward, the Board will continue the planning process. A Board subgroup is looking at its governance structure. Priorities for the next three years will be identified.

Increase the association's electronic communication capabilities. Electronic bulletin boards and listservs provide excellent communication opportunities within the ACRL membership, as well as networking opportunities with other organizations. During the year, ACRL will improve its existing electronic communication capabilities (e.g., ACRLSource a.k.a., ACRL Reference Shelf, CERL NewsNet). In addition, ACRL will be on the ALA gopher, and will establish a private leadership listserv (ACRLEADS) and a discussion listserv (ACRL-FORUM) available to anyone who wishes to subscribe. 


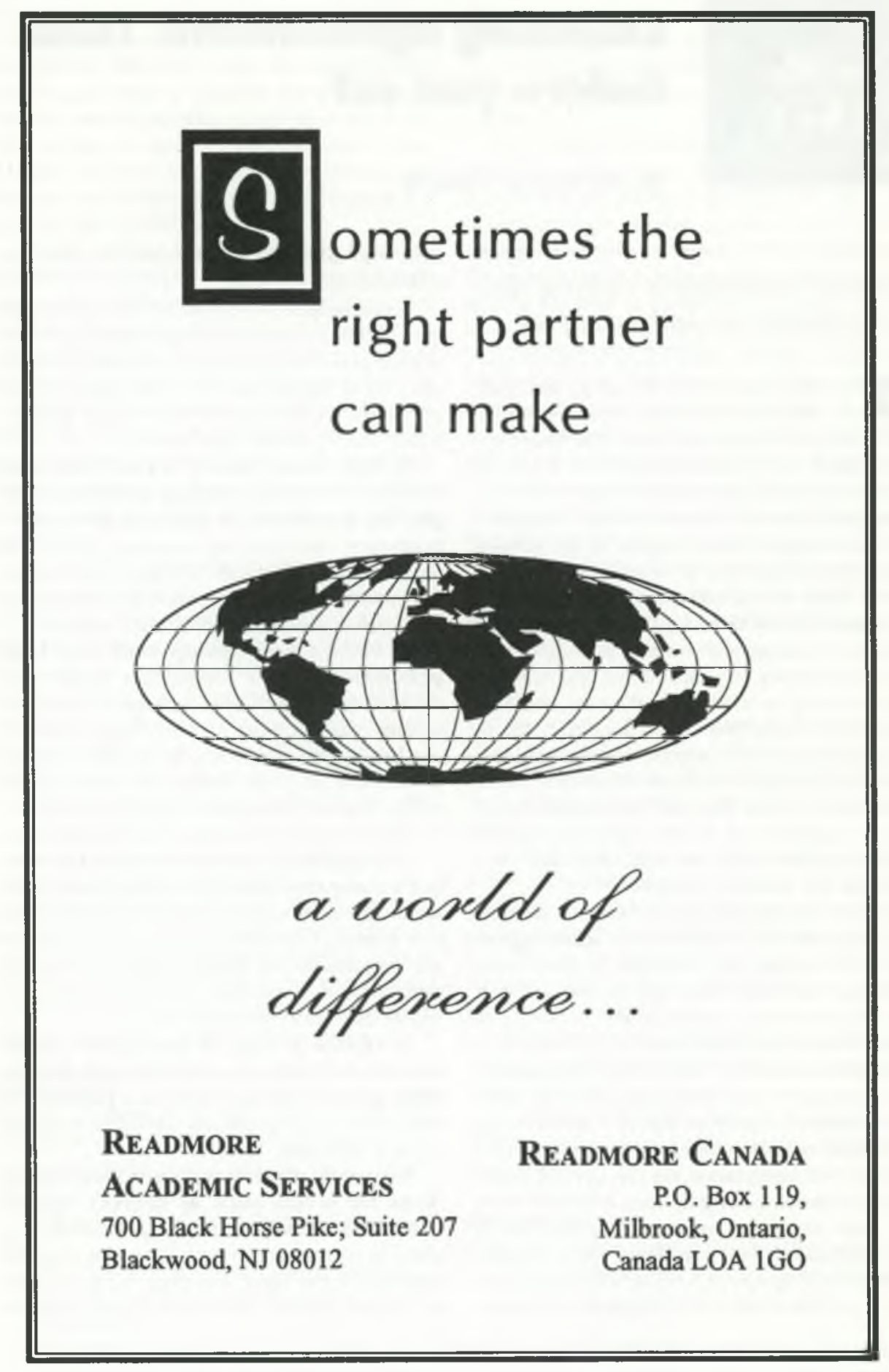

